International Journal of Earth Sciences

June 2009, Volume 98, Number 4, Pages 823-837

http://dx.doi.org/10.1007/s00531-008-0334-z

(c) 2009 Springer. Part of Springer Science+Business Media
Archimer, archive institutionnelle de l'Ifremer http://www.ifremer.fr/docelec/

The original publication is available at http://www.springerlink.com

\title{
Deep sea in situ excess pore pressure and sediment deformation off NW Sumatra and its relation with the December 26, 2004 Great Sumatra- Andaman Earthquake
}

\author{
Nabil Sultan ${ }^{1,{ }^{*}}$, Antonio Cattaneo ${ }^{1}$, Jean-Claude Sibuet ${ }^{1}$, Jean-Luc Schneider ${ }^{2}$ and the Sumatra \\ Aftershocks team
}

\author{
${ }^{1}$ Ifremer, Brest - GM, BP70, 29280 Plouzané, France \\ 2 Université Bordeaux 1, OASU, CNRS-UMR 5805 "EPOC”, 33405 Talence cedex, France \\ *: Corresponding author : Sultan N., email address : nabil.sultan@ifremer.fr
}

\begin{abstract}
:
The swath bathymetric data acquired during the "Sumatra Aftershocks" cruise from the Sunda trench in the Indian Ocean to the north of the Sumatra Island imaged several scars and deposits. In situ pore pressure measurements using the Ifremer piezometer and coring demonstrate that high excess pore pressure and sediment deformation was generated by a recent event in the scar of the slope failure zone identified by J.T. Henstock and co-authors. This excess pore pressure is localized in the upper sedimentary layers and is not related to an interplate subduction process. Numerical simulations of the hydrological system that take into account the hydro-mechanical properties of the upper sediment layer show that the excess pore pressure and sediment deformations could be generated at the time of the December 26, 2004 Great Sumatra Earthquake.
\end{abstract}

Keywords: Earthquake - Pore pressure - Slope failure - Sumatra - Tsunami 


\section{Introduction}

The December 26, 2004 devastating Great Sumatra-Andaman Earthquake was the biggest earthquake ever recorded since the 1960 Chilean earthquake (Stein and Okal 2005). The earthquake was initiated close to the slab interface, at a depth of $20-30 \mathrm{~km}$, in the vicinity of an Indonesian fore-arc indentation. The rupture propagated $1300 \mathrm{~km}$ northwards from the epicentral region located at $3.3^{\circ} \mathrm{N}$, with an average propagation velocity of $2.1 \mathrm{~km} \mathrm{~s}-1$ (Park et al. 2005; Bilham et al. 2005; de Groot-Hedlin et al. 2005). For such a large earthquake, aftershock ruptures may last for several years and their location can be used to define the position of the seismically active region.

The "Sumatra Aftershocks" cruise onboard the French R/V Marion Dufresne took place during Summer 2005 (July, 14 - August, 9) to 1) record aftershocks and localize post-seismic motions using Ocean Bottom Seismometers within a relatively short delay after the main seismic event (Sibuet et al. 2007) and 2) investigate submarine mass wasting processes possibly associated with recent earthquakes. Even if the main trigger mechanism for the tsunami appears to be linked to tectonic movements in the area of active convergence between the Indo-Australian and the Southeast Asian plates (Stein and Okal 2005; Puspito 2002), the role of submarine slope instabilities and sediment failures in tsunami generation remains unknown and deserves further investigation. A Special Issue of Marine Geology (Pelinovsky and Tinti 2005) summarized a series of case histories where the role of mass wasting in the generation of tsunamis may have been either the main factor responsible for the destructive wave (e.g. the 1929 Grand Banks tsunami - Fine et al. 2005) or could have played a relevant role in amplifying the effect of earthquake-triggered tsunamis (e.g., in the Marmara Sea - Hébert et al. 2005).

In order to relate tectonic activities with seafloor failure features, swath bathymetric data together with $3.5 \mathrm{kHz}$ seismic profiles were acquired on a $40 \times 200$ nautical miles $(74 \times 370$ $\mathrm{km}$; ca. $27,000 \mathrm{~km}^{2}$ ) box oriented SW-NE between the India-Indonesian water limit and the north-western tip of Sumatra Island [Figure 1- Sibuet et al. 2007; Singh et al. 2005].

One of the main aims of this work is to explore the possible links between submarine mass wasting processes and the most developed landslide identified by Henstock et al. (2006) along the toe of the prism on one hand and the Great Sumatra Earthquake event on the other. Therefore, in addition to the acquired bathymetric data, we carried out during the "Sumatra Aftershocks" cruise heat flow measurements, sediment coring and in situ pore pressure monitoring using the Ifremer piezometer.

\section{Materials and methods}

\subsection{Swath bathymetry and $3.5 \mathrm{kHz}$}

In order to investigate the sea-floor morphology, swath bathymetric mapping was conducted during "Sumatra Aftershocks" 2005 cruise. Multibeam swath bathymetric data, together with $3.5 \mathrm{kHz}$ seismic profiles, were acquired with a THALES Sea Falcon 11 integrated system. The across-track resolution of the bathymetry depends upon the measured depth and is typically equal to depth/100. In the present work, the multibeam bathymetry data were gridded at 100 meters.

\subsection{Coring}

Twelve gravity and piston cores were recovered with in situ temperature measurements using autonomous digital temperature probes fitted on gravity core barrels (see Sibuet et al. 2007). In the following, only three sediment cores and one in situ pore pressure measurement from the HMS Scott landslide area are presented and discussed (Figure 2). 


\subsection{Piezometer}

The study area is characterized by several submarine slope instability structures, but it is difficult from the morphology alone to distinguish sediment failures triggered by the Great Sumatra Earthquake from older sediment failures. One of the key parameters for the detection of co-seismic irreversible sediment deformations is the long-term dissipation process of the excess pore pressure generated during earthquake shaking. That is why the main aim of the use of the Ifremer piezometer in this project was to detect a change of the pore pressure generated by the last major earthquakes events (December 2004 and March 2005). For this purpose, a piezometer was deployed to the North of the observed mass wasting area (MD05-PZ1; see Figure 2 for location). The location of MD05-PZ1 coincides with that of core MD05-2975.

The Ifremer piezometer is a free-fall device similar to the Pop Up Pore Pressure Instrument (Schultheiss and McPhail 1986) with a sediment-piercing lance attached to a recoverable instrument part. It is ballasted with lead weights to penetrate a range of sediment types in water depths of up to $6000 \mathrm{~m}$. The length of the used lance depends upon the stiffness of the sediment. For soft sediment, a 12-metres lance can be used successfully. Pore pressures are measured relative to hydrostatic pressure at maximum 5 ports on the $60 \mathrm{~mm}$ diameter lance using specially adapted differential pressure transducers connected to the pressure ports and the open sea-water. The piezometer pore pressure sensors have a resolution of \pm $0.2 \mathrm{kPa}$ (Sultan et al. 2007). The Ifremer piezometer can be used in two modes: 1) long term measurements where the equilibrium pore pressure can typically be reached after several days (depending on the permeability of the medium and the depth of the sensor) and 2) short term measurements where the equilibrium pressure is evaluated by plotting the pressure record versus the reciprocal of time and extrapolated to $1 /$ time $=0$, a technique developed by Davis et al. (1991) and Fang et al. (1993) and successfully used by Urgeles et al. (2000).

Figure 3 shows an example of pore pressure monitoring acquired from the Gulf of Guinea deepwater sediments (with permeability coefficients between $10^{-8}$ and $3.10^{-8} \mathrm{~m} / \mathrm{s}$ ) and used in the present work to validate the short-term piezometer measurements carried out during the "Sumatra Aftershocks" cruise. Pore pressures were measured at two different levels (Figure 3-a: $11.6 \mathrm{mbsf}$ and Figure 3-b: $10.1 \mathrm{mbsf}$ ). For the two sensors, the pore pressure equilibrium was reached after around 2 days. The equilibrium pressure for the shallower sensor is found equal to $9.5 \mathrm{kPa}$ while it was equal to $11.2 \mathrm{kPa}$ for the deeper sensor. The use of the Davis et al. (1991) method after only 3.5 hours recording gave equilibrium pressures of $11 \mathrm{kPa}$ at $11.6 \mathrm{mbsf}$ and $10 \mathrm{kPa}$ at $10.1 \mathrm{mbsf}$. The maximum mismatch between the real equilibrium pore pressures and extrapolated ones is acceptable and comparable to the precision of the pore pressure sensors $( \pm 0.2 \mathrm{kPa})$.

\section{Results}

\subsection{Swath bathymetry}

Swath bathymetry data revealed several morphotectonic features. The study area (Figure 2) is characterized by very steep slope angles locally reaching $30^{\circ}$. Several ridges are collapsed and/or sliced by major or secondary faults (Sibuet et al. 2005). A number of slope failure scars and deposits were also identified in the search area in Figure 1. However, no major submarine landslides holding the potential to contribute to the December 2004 tsunami generation were discovered.

The submarine landslide already identified by the British R/V HMS Scott at the frontal area facing the Sumatra trench (Henstock et al. 2006) is presented in Figure 2 with the bathymetry acquired during the 'Sumatra Aftershocks' cruise. The slope failure occurs in water depths ranging between 3300 and $4300 \mathrm{~m}$. Figure 2 shows the presence of a ridge crest to the north of the main landslide scarp eroded most likely by uplifting and sediment incision. This eroded crest was considered as part of the slide-scar complex by Henstock et al. (2006). The 
western boundary of the eroded ridge is indicated in Figure 4 (points A1 and E1). Figure 4 shows that the landslide is characterized by a series of horseshoe-shaped headwall scars and sediment deposits with positive relief. Figure 5-a shows three NE-SW cross sections across the northern part of the slope failure zone (A-A, B-B and E-E). The boundary of the eroded ridge crest (arrows A1 and E1) and 5 scarps (arrows A2, A3, B1, E2 and E3) already described by Henstock et al. (2006) as folds/scarps due to faulting are also indicated in Figure 5-a. Figure 5-b displays two other NE-SW cross sections (C-C and D-D) across the 3 slides indicated in Figure 4 showing several scarps, which probably correspond to several phases of failure. The slope angles determined along the C-C and E-E cross-sections are presented in Figure 5-c and it indicates that along those two cross-sections, the maximum slope angle is equal to 17 degrees. Several topographic features can be identified in Figure 2 and Figure 4 in an area of about $10 \times 8 \mathrm{~km}$ that is 1 to $10 \mathrm{~km}$ away from the base of the accretionary prism front.

Figure 6 shows two $3.5 \mathrm{kHz}$ profiles acquired across the deposit area, the fracture zone and the block field (for location see Figures 2 and 4). Figure 6-a shows the presence of 1) a lensshaped sediment accumulation with an irregular surface at the base of the accretionary prism front, and 2) a sediment deposit covering the base of some small blocks. These two observations confirm the existence of distinct sliding phases of different ages, since some blocks appear to represent the expression of ancient events. The $3.5 \mathrm{kHz}$ profile presented in Figure 6-b shows the presence of a seafloor escarpment with NW-SE trend.

\subsection{Coring}

\subsubsection{Sedimentology}

Three cores were recovered from the HMS Scott landslide area (Figure 2, Figure 4 and Table 1). Two cores were acquired from the slope and one core in the trench basin at the base of the slide. Core logging of physical properties (gamma density, P-wave velocity and magnetic susceptibility) was conducted onboard on unopened $1.5 \mathrm{~m}$-long core sections through a GEOTEK core logging device (http://www.geotek.co.uk/). SCOPIX (X-ray) images were obtained at the Bordeaux 1 University. Core description (including photo and X-ray images) was not possible at the level where geotechnical samples were taken in cores MD05-2972 and MD05-2975 because of the destructive nature of the geotechnical measurements.

Core MD05-2975 is a gravity core that recovered $5.72 \mathrm{~m}$ of sediment with a $12 \mathrm{~m}$ tube. The core is located ca. $4 \mathrm{~km}$ upslope of slide scar 3 (to the north; Figure 4) at the same location of piezometer MD05-PZ1. The sediment is composed of finely laminated silty clay with traces of black organic matter in the upper $1.8 \mathrm{~m}$ (Figure 7-a). The upper $0.5 \mathrm{~m}$ shows evidence for some bioturbation and higher water content. From 1.8 to $2.5 \mathrm{~m}$ bioturbation is more visible and there are two levels richer in bioclast (mostly pteropods, Figure 7-a) that could account for a slightly reduced unit weight at this level. The lithology is remarkably homogeneous in the interval from 2.5 to $4 \mathrm{~m}$ (Figure 7-b to -e). X-ray images and, less evidently, core photos, reveal an interval with bioturbation and perturbation of sedimentary structures (especially from 4.4 to $4.8 \mathrm{~m}$ - Figure $7-b$ to $-f)$.

Core MD05-2972 is a $2.94 \mathrm{~m}$ long gravity core located away from the slide scars identified by Henstock et al. (2006) and presented in Figure 4. The core barrel bent after ca. $3 \mathrm{~m}$ of penetration in indurated sediment. The core is composed of finely laminated silty clay in the upper 2 meters, and then a lithologic change occurs. At 2-2.09 $\mathrm{m}$ the amount of carbonate content (bioclasts) is higher and could account for a drop in unit weight value, then from $2.4 \mathrm{~m}$ to the base of the core several layers of fine to medium sand (up to few $\mathrm{cm}$ thick) appear (Figure 8). Figure 8 shows a detail of cross-laminated, mica-rich, sharp-based sand layers with normal grading, that contrast with the alternating mud with very thin silt laminae of the upper part of the core (Figure 8-a to -d). Moderate bioturbation is present in the upper 10 $\mathrm{cm}$ and much more developed in the lower unit, where it disrupts the geometry of some of the sand layers. 
Core MD05-2981, located on the basin floor about $14 \mathrm{~km}$ from the foot of the slope affected by the landslides and seaward of the blocks/bulges, recovered $10.66 \mathrm{~m}$ of sediment (Figure 4). The whole core is composed of alternating mud with sets of silt to very fine sand laminae. The thickest sand layer is $20 \mathrm{~cm}$, but the most common deposits are 2 to $5 \mathrm{~mm}$ thick silt to very fine sand layers occurring in sets of 5 to $15 \mathrm{~cm}$ separated by 20 to $40 \mathrm{~cm}$ thick intervals of mud (Figure 6-c). The layers are downwarped all along the core, with deformation up to 5 $\mathrm{cm}$ from the center of the core to the sides, due to piston suction. However, the overall stratigraphic succession of this core is preserved and represents alternating thin-bedded turbidites with possible hemipelagic sediment corresponding to plane parallel layering on 3.5 $\mathrm{kHz}$ profiles.

Figure 9-a shows the unit weight profile obtained from the attenuation of gamma rays through core MD05-2975, (core location in Figures 2 and 4). A linear increase of the unit weight with depth until 1.8 mbsf is followed by constant values down to 3.5 to $4 \mathrm{mbsf}$ and then a decrease down to the base of the core. This shape of the unit weight profile is similar for other physical measurements carried out on core MD05-2975 as the P-wave velocity (Figure 9-b) and the undrained shear strength (Figure 9-e). As expected, the water content (Figure 9-c) and the liquidity index (Figure 9-d) display an opposite profile. The decrease of the unit weight below $3.5 \mathrm{~m}$ in core MD05-2975 is an evidence of remolded sediment, which we relate to in-situ deformation though sediment remolding during coring cannot be totally ruled out. From visual description and X-ray (Figure 7) this remolded sediments appear at $4.5 \mathrm{~m}$ depth, rather than the $3.5 \mathrm{~m}$ shown in Figure 9.

The unit weight and the $P$ wave profiles of the core MD05-2972 presented in Figure 9-a and Figure 9-b shows a continuous increase with depth. The water content and the liquidity index profiles show a continuous decrease with depth (Figure 9-c and Figure 9-d). The undrained shear strength profile shows also a linear increase with depth (Figure 9-e) but at the bottom of the core we measured undrained shear strength of about $40 \mathrm{kPa}$ which demonstrates the highly overconsolidated state of the sediment at around $2.8 \mathrm{mbsf}$.

The unit weight profile from the core MD05-2981 shows constant values of the unit weight all over the $10.7 \mathrm{~m}$ core length. The absence of any unit weight gradient demonstrates the underconsolidated state of the sediment at MD05-2981 site.

\subsubsection{Compressibility and permeability tests}

The compressibility tests were carried out using the oedometer with incremental loading. Six oedometer tests were carried out on samples from cores MD05-2972 and MD05-2975. The main aim of these oedometer tests is to evaluate the consolidation state of the sediment. Results of the consolidation tests in terms of compressibility for core MD05-2975 are presented in Figure 10-a. Sediment sample from the level 4 mbsf is characterized by high initial void ratio and a high compressibility. Permeability coefficients of the sediment from cores MD05-2972 and MD05-2975 were also determined at different consolidation state and different porosity. Figure 10-b shows the variation of the permeability coefficients as a function of the void ratio indicating a quasi-constant slope variation for the 4 samples from MD05-2975.

Figure 11 shows the Over-Consolidation Ratio (OCR) derived from the oedometer tests indicating that the sediment from core MD05-2972 and the upper sediment from core MD052975 are in an over-consolidated state. Sediment from core MD05-2975 at around 4 mbsf indicates a low OCR which is probably the expression of the remolded state of the sediment at this level. The origin of the high OCR could be the stress tensor generated by the upper movement of the ridge and the erosion. If it is the case, it is obvious that the stress tensor like the ridge morphology is irregular and the stress is higher at the site MD05-2972 (maximum OCR= 6.8) than at the site of MD05-2975 (2.9).

\subsection{Piezometer}

Figure 12 shows the dissipation of the initial impulsion (temperature and pore pressure) generated by the penetration of the piezometer MD05-PZ1. The MD05-PZ1 piezometer was 
$3.51 \mathrm{~m}$ long and it was equipped with three sensors (at $-0.51 \mathrm{~m},-2.01 \mathrm{~m}$ and $-3.51 \mathrm{~m}$ from the top of the lance, which corresponds to the seafloor once the piezometer stops penetrating). The dissipation curves of the pore pressure presented in Figure 12 depend mainly on the hydraulic diffusivity of the sediment. The temperature and pore pressure at equilibrium are estimated from values of Figure 12 by drawing the excess pore pressure and the temperature versus the inverse of time and extrapolating these values to $1 /$ time $=0$ (Figure 13).

Figure 14-a shows the excess pore pressure versus depth at site MD05-PZ1. The comparison between the hydraulic gradient obtained from MD05-PZ1 and the vertical effective stress obtained from the unit weight of the core MD05-2975 shows that the pore pressure at $3.51 \mathrm{mbsf}$ (around $13.5 \mathrm{kPa}$ ) corresponds to about $65 \%$ of the vertical lithostatic stress. Figure 14-b shows the temperature versus depth at the site MD05-PZ1. The thermal gradient derived from the temperature measurements is around $182^{\circ} \mathrm{C} / \mathrm{km}$ and is more than three times higher than the background thermal gradients measured from the study area (Sibuet et al. 2005).

\section{Discussion}

\subsection{Seafloor morphologic features}

From the morphology presented in Figures 2 and 4 it is clear that several phases of failure have contributed to the present morphology of the studied ridge. At least three distinct slides, that may or may not have occurred at the same time and under the same triggering mechanism, are shown in Figure 4. Several other landslides and scarps inside and outside the three main landslides are also indicated in Figure 4 (points A2, A3, B1, C1, D1, D2, E2, E3).

From Figure 6, it seems that several small blocks possibly associated with a major landslide event were present before the development of a more recent sediment accumulation. According to Henstock et al. (2006), those features originated from the ridge flank and probably travelled up to $15 \mathrm{~km}$ from the headwall scarp. However, if we compare the size of the largest morphologic features with the topographic profiles across the scar and the headwall heights (see Figure 5-b), it seems that they are too large to be considered as slided blocks coming from this scar.

\subsection{Excess pore pressure: source and regime}

The excess pore pressure measured at site MD05-2975 could be the result of several events and distinct triggering mechanisms. In the following we will focus on four questions: 1 ) Is the excess pore pressure profile in a steady state or a transient regime? 2) Is the excess pore pressure related to the December, 26 Great Sumatra Earthquake? 3) What is the source of the excess pore pressure? and 4) Is there any link between the measured excess pore pressure and one of the observed landslide?

Excess pore pressure: steady state versus transient regime

For an hydraulic steady state regime (under one-dimensional conditions) and by neglecting the storage effects, the Darcy equation and the flow continuity lead to:

$$
k \frac{\partial h}{\partial z}=\text { constant }
$$

Where $k$ is the permeability coefficient (or hydraulic conductivity) and $h$ is the hydraulic head. Properties and parameters used in this study are listed in Table 2. 
By applying equation [1] for the in situ pore pressure measurements presented in Figure 14-

a, one can expect for a steady state regime a rate of $119\left(=\frac{\left.\frac{\Delta h}{\Delta z}\right|_{\text {between } 2 \text { and } 3.5 \mathrm{~m}}}{\left.\frac{\Delta h}{\Delta z}\right|_{\text {between } 0.5 \text { and } 2 \mathrm{~m}}}=\frac{\frac{13.2-1.3}{1.5}}{\frac{1.3-1.2}{1.5}}\right)$

between the permeability coefficient above and below $2 \mathrm{~m}$. On the other hand, permeability measurements carried out on samples from MD05-2975 do not show this important permeability discontinuity all over the core (see Figure 10-b). This inconsistency between flow continuity constrained by the hydraulic steady state regime and the measured permeability coefficients shows that the upper sediment is in a transient state regime where the hydraulic equilibrium is not yet reached.

For the transient regime, the one-dimensional transient fluid flow is described by:

$\frac{\partial U(z, t)}{\partial t}=\frac{\partial}{\partial z} D_{h}(z) \frac{\partial U(z, t)}{\partial z}$

where $D_{h}(z)$ represents the hydraulic diffusivity of the sediment and is directly related to the permeability coefficient. $U(z, t)$ is the excess pore pressure which varies with the time $t$ and the depth in the vertical direction $z$.

As a hypothesis, we consider an initial excess pore pressure profile corresponding to $90 \%$ of the lithostatic stress in the area where we have identified the remolded sediments (Figure 15a). We also suppose that this initial state of the pore pressure build-up corresponds to the $26^{\text {th }}$ of December 2004 earthquake. The void ratio and the permeability design profiles (Figure 15-b and -c) were computed from the unit weight profile of core MD05-2975 (Figure $9-a)$ and the permeability coefficients values presented in Figure 10-b.

Using equation [2], with the initial pore pressure presented in Figure 15-a and the two design profiles of the void ratio and the permeability coefficients presented in Figure 15-b and Figure $15-c$, it is possible to determine the evolution of the pore pressure profile as a function of time (Figure 15-a). The boundary conditions we considered in this work are zero excess pore pressure at the seabed level and impermeable layer at the base of the sediment profile. Several calculations were carried out in order to identify the most suitable initial excess pore pressure. We find that $90 \%$ of the vertical lithostatic stress as an initial condition is the most suitable value to explain our pore pressure measurements. The pore pressure profile computed 218 days after the Great Sumatra Earthquake corresponds to the period of the in situ pore pressure monitoring (Figure 15-a). Figure 15-a shows a very good agreement between the predicted excess pore pressure and the in situ pore pressure measured during the "Sumatra Aftershocks" cruise. Such a good agreement between calculated and measured excess pore pressure supports the likelihood that the high excess pore pressure was generated at the time of the December, 26 Great Sumatra Earthquake.

The shape of the thermal gradient (linear) measured at MD05-PZ1 differs from the pore pressure one. The origin of the high thermal gradient and of the high hydraulic gradient at the site MD05-PZ1 is therefore not the same. Indeed, the linear shape of the thermal gradient suggests that the temperature field in this area presents a permanent regime over the first $3.5 \mathrm{~m}$ while the hydraulic gradient corresponds to a transient regime. The high linear increase of the temperature with depth must be related to a continuous process compatible with the constant temperature gradient and not to a single catastrophic movement as in an earthquake.

\subsubsection{Pore pressure source: earthquake shaking or slab subduction?}

Loose coarse grained sediments and normally consolidated fine grained sediments tend to contract during shearing. In saturated sediments, volume reduction can only occur if pore water could be drained. When the loading rate is fast (earthquake) compared to flow rate, positive excess pore pressure is generated, resulting in an equal decrease of the effective confining stress. When sand is loose enough and the magnitude of the cyclic shear stress is 
high enough, the vertical effective stress drops to zero. For sands and silty sands, this phenomenon is known as sediment liquefaction and is generally associated with slope instabilities, sediment failures, ground settlement, and occasionally sand boils. For soft clays, cyclic loading generated by an earthquake may induce the degradation of sediment stiffness and shear strength (Idriss et al. 1976 and 1978), but also an increase in pore pressure (Biscontin and Pestana 2006).

Alternatively, slab subduction produces excess pore pressures independently of

earthquakes: high porosity sediment is dragged down under the accretionary prism leading

water to squeeze out from sediment and pressurizing the entire prism (Von Huene and Lee

1982; Saffer et al. 2000). Therefore, the main question remains whether the origin of the

monitored excess pore pressure is related to slab subduction or to the earthquake shaking?

One of the main divergences between these two processes (earthquake versus slab subduction) is the position of the pore pressure source. While the pore pressure source is deep and generated at or below the décollement zone for subduction, it is contained in the upper soft sediment for earthquake cyclic loading (Biscontin and Pestana 2006). Modeling results presented in Figure 15-a show that the measured pore pressure could be a direct consequence of the December, 26 Great Sumatra Earthquake. In the following, a deep source pore pressure will be considered to evaluate any possible link between the measured pore pressure and the deep slab subduction movement.

Sediment porosities and permeabilities from the margin wedge above the décollement surface are expected to decrease with depth below the seafloor. Therefore, we can anticipate an increase of the pore pressure gradient $\left(\frac{\partial U(z, t)}{\partial z}\right)$ with depth in order to insure the flow continuity. Our working hypothesis is to consider over the margin wedge a lithology similar to core MD05-2975. From the porosity, the permeability and the bulk unit weight of the sediment, it is possible to quantify by a back analysis the evolution of the excess pore pressure and the stress state over the geological formation (see for instance Gibson, 1958; Gordon and Flemings, 1998; Dugan and Flemings, 2000). For that, the principle of the effective stress that defines the vertical effective stress in porous media $\left(\sigma_{v}^{\prime}\right)$ as the difference between the vertical total stress $\left(\sigma_{v}\right)$ and pore fluid pressure $(u)$ is used:

$$
\sigma_{v}^{\prime}=\sigma_{v}-u
$$

In equation 3, the pore fluid pressure $u$ is the sum of the hydrostatic pressure $\left(\rho_{w} g z\right)$ and the excess pore pressure $(U)$ with $\rho_{w}$ is the water unit weight and $g$ the gravitational constant

$$
u=U+\rho_{w} g z
$$

The link between the void ratio $e$ and the vertical effective stress is considered through the following equation:

$$
e=e_{0}-\lambda \cdot \ln \left(\frac{\sigma^{\prime}{ }_{v}}{\sigma_{0}^{\prime}}\right)
$$

where $e_{0}$ is a reference void ratio at a reference vertical effective stress $\sigma_{0}^{\prime}$, and $\lambda$ is the compression index.

The vertical effective stress, the porosity, the permeability coefficient, the hydraulic diffusivity and the thermal diffusivity are calculated using the principle of the effective stress (eq. 3) and the compressibility curves (eq. 5) defining the link between the void ratio $e$ and the vertical effective stress. The compressibility index $\lambda$ is determined from Figure 10-a. 
Three source depths of the pore pressure are considered: at 100 meters below seafloor (mbsf), $50 \mathrm{mbsf}$ and $25 \mathrm{mbsf}$. For each pore pressure source, the amount of the excess pore pressure is supposed to be equal to $25 \%, 50 \%, 85 \%$ and $95 \%$ of the lithostatic stress. The calculation results of the pore pressure profiles are presented in Figure 16-a (source at $100 \mathrm{mbsf}$ ), Figure 16-b (source at $50 \mathrm{mbsf}$ ) and Figure 16-c (source at $25 \mathrm{mbsf}$ ). For the twelve calculations, the calculated excess pore pressure diverges from the observed one showing that either the source (location and amplitude) of the excess pore pressure or the used permeability profile presented in Figure 10-b and corresponding to homogenous sediment is not compatible with the measured excess pore pressure.

Other hypothesis is to consider that the permeability coefficient could be strongly modified by the high excess pore pressure. Indeed, hydro-fracturing could be generated when the difference between the fluid pressure and least principal (confining) stress becomes close to zero. Hydro-fracturing generates Mode I fractures (displacement perpendicular to fracture) and can induce a drastic increase of the permeability of the medium. Figure 17-a shows the pore pressure profile calculated for a permeability increase $\left(5.10^{-5} \mathrm{~m} / \mathrm{s}\right)$ generating hydrofracturing below $5 \mathrm{~m}$. A relatively good agreement can be observed between the measured pore pressure and the calculated one (Figure 17-a). On the other hand, the hydro-fracturing which can be derived from the permeability coefficient and the hydraulic head will generate high Darcy velocities $v(z)$ :

$$
v(z)=k(z) \frac{\partial h}{\partial z}
$$

Temperature field can be also used to verify the hypothesis of a deep pore pressure source. Indeed, water advection from hot deep décollement level can be the cause of an increase of the thermal gradient. For steady-state thermal regime, the temperature can be evaluated by the following equation:

$$
\frac{\partial}{\partial z}\left(D_{T}(z) \frac{\partial T}{\partial z}\right)=v(z) \frac{\partial T}{\partial z}
$$

with $D_{T}(z)$ corresponding to the thermal diffusivity and $v(z)$ to the vertical water velocity.

Because the hydro-fracturing and the high Darcy velocities, the temperature profile calculated using equation 7 and presented in Figure 17-b highly overestimates the in situ measured temperature. Thus, the high permeability generated by hydro-fracturing and the deep pore pressure source at the subduction level can be also ruled out.

\subsubsection{Excess pore pressure and sediment deformation}

The pore pressure measurements and the calculation results show that the most likely origin of the excess pore pressure seems to be a local deformation of the upper sediment layers generated in the same time-period of the December, 26 Great Sumatra Earthquake. The build-up pore pressure during the earthquake was certainly higher than the value measured in July 2005. From the calculation it was evaluated to be around $90 \%$ of the lithostatic stress. According to Ishihara (1993), silty sands or sandy silts containing some amount of fines may behave as liquefiable materials with an excess pore pressure values equal to 90 to 95 percent of the initial confining stress.

The high residual excess pore pressure measured in July 2005 is a clear indication of a local sediment deformation without any slope failure generation at the MD05-PZ1 site. For any submarine slope with a normally consolidated soil and a slope angle larger than 10 degrees as it is shown in Figure 5-c, an important build up pore pressure as the one measured at MD05-PZ1 will cause a slope to fail. For the MD05-PZ1 area, the highly over-consolidated upper sediment (Figure 11) has prevented the slope failure to occur.

OCR values obtained from MD05-2975 and MD05-2972 cores have shown two different state of consolidation at the two different sites. This different consolidation state is obviously related to the irregular ridge morphology and erosion: core MD05-2972 recovered ancient 
sediment coming from the erosion and denudation of the inner part of an anticline, MD052975 sampled likely younger sediment.

\section{Conclusion}

The bathymetric data acquired during the "Sumatra Aftershocks" cruise show the existence of several scars and deposits in the study area from the base of continental rise up to the accretionary prism and the continental slope flanking the Aceh forearc basin. The landslide identified by Henstock et al. (2006) seems to be the result of several phases of failure. Several blocks, probably related to the main landslide described by Henstock et al. (2006), were identified in the deep depositional area. From the $3.5 \mathrm{kHz}$ profile data it seems clear that these blocks are the expression of several ancient events rather than one recent landslide.

Core MD05-2975 recovered from the HMS Scott landslide (Henstock et al. 2006) indicates the existence of remolded sediment. The in situ pore pressure measurement using a piezometer at the same site demonstrates that an excess pore pressure was generated by a recent event. The calculation results have shown that the excess pore pressure is in a transient regime. Moreover, the pore pressure measurements and the calculation results show that the most likely origin of the excess pore pressure seems to be a local deformation of the upper sediment layers generated in the same time-period than the December, 26 Great Sumatra Earthquake.

Finally, the high thermal gradient and the high hydraulic gradient at Site MD05-PZ1 certainly represent the expression of two distinct phenomena. Indeed, while the thermal gradient presents a permanent regime over the first $3.5 \mathrm{~m}$ (linear temperature profile), the hydraulic gradient corresponds to a transient regime. The high linear increase of the temperature with depth must be related to a continuous process and not to a single catastrophic movement such as an earthquake.

\section{Acknowledgements}

The "Sumatra Aftershocks" cruise was organized in collaboration between the Institut Français de Recherche pour l'Exploitation de la Mer (Ifremer), the Institut Polaire Français Paul Emile Victor (IPEV) and the Agency for the Assessment and Application of Technology, Indonesia (BPPT). We thank captain François Duchene and the crew of the R/V Marion Dufresne for their dedicated work during the MD149 «Sumatra Aftershocks» cruise, as well as the technical staff of the Institute Paul-Emile Victor (IPEV) led by B. Ollivier for their constant and precious help. Financial supports were provided by the Agence Nationale de la Recherche (ANR), the Délégation Inter-ministérielle pour le Tsunami (DIPT), Ifremer and IPEV. The authors are grateful to Tim Henstock, Giovanna Biscontin and Miquel Canals for their constructive comments.

\# 'Sumatra Aftershocks' team: J.-C. Sibuet, S. Singh, R. Apprioual, N.C. Aryanto, J. Begot, A. Cattaneo, A.P.S. Chauchan, R. Creach, J. Crozon, A. Domzig, N. Falleau, D. Graindorge, F. Harmegnies, Y. Haryadi, F. Klingelhoffer, S.K. Kolluru, J.-Y. Landuré, C. Le Lann, J. Malod, A. Normand, G. Oggian, C. Rangin, D. Restunin Galih, J.-L. Schneider, N. Sultan, M. Taufik, M. Umber and $\mathrm{H}$. Yamaguchi. 


\section{References}

Bilham R, Engdahl R, Feldl N et al (2005) Partial and Complete Rupture of the IndoAndaman Plate Boundary. Seismological Research Letters 76: 299-311

Biscontin G, Pestana JM (2006) Factors affecting seismic response of submarine slopes. Natural Hazards and Earth System Sciences 6: 97-107

Davis EE, Horel GC, MacDonald RD (1991) Pore pressures and permeabilities measured in marine sediments with a tethered probe. Journal of Geophysical Research 96: 5975-5984

De Groot-Hedlin C.D (2005) Estimation of the rupture length and velocity of the Great Sumatra earthquake of Dec 26, 2004 using hydroacoustic signals. Geophysical Research Letters. Doi:10.1029/2005GL022695

Dugan B, Flemings PB (2000) Overpressure and fluid flow in the New Jersey continental slope: Implications for slope failure and cold seeps. Science 289: 288-291.

Fang WW, Langseth MG, Schultheiss PJ (1993) Analysis and application of in situ pore pressure measurements in marine sediments. Journal of Geophysical Research 98: 79217938

Fine IV, Rabinovich AB, Bornhold BD, Thomson RE, Kulikov EA (2005) The Grand Banks landslide-generated tsunami of November 18, 1929: preliminary analysis and numerical modeling. Marine Geology 215: 45-57

Gibson RE (1958) The progress of consolidation in a clay layer increasing in thickness with time. Geotechnique 8: 171-182.

Gordon DS, Flemings PB (1998) Generation of overpressure and compaction-driven fluid flow in a Plio-Pleistocene growth-faulted basin, Eugene Island 330, offshore Louisiana. Basin Research 10(2): 177-196.

Hébert H, Schindelé F, Altinok Y, Alpar B, Gazioglu C (2005) Tsunami hazard in the Marmara Sea (Turkey): a numerical approach to discuss active faulting and impact on the Istanbul coastal areas. Marine Geology 215: 23-43

Henstock JH, McNeil LC, Tappin DR (2006) Seafloor morphology of the Sumatran subduction zone: surface rupture during megathrust earthquakes?. Geology 34: 485-488

Idriss IM, Dobry R, Doyle EH, Singh RD (1976) Behavior of soft clays during earthquake loading conditions. In Proceedings of the Offshore Technology Conference, Houston, Texas, OTC 2671

Idriss IM, Dobry R, Singh RD (1978) Nonlinear behavior of clay soils during cyclic loading. Journal of the Geotechnical Engineering Division ASCE 104(12): 1427-1447

Ishihara K (1993) Liquefaction and flow failure during earthquakes. Geotechnique 43: 351415.

Park J, Anderson K, Aster R, Butler R, Lay T, Simpson D (2005) Global Seismographic Network records the Great Sumatra-Andaman Earthquake. Eos 86: 57-64 
Pelinovsky E., Tinti S (2005) Tsunamis in the Pacific, in the Atlantic and in Europe: relevant cases and hazard evaluation. Marine Geology 215: 1-106

Puspito NT (2002) Tsunami and earthquake activity in Indonesia, In A.B. Rabinovich, W. Rapaz (Eds.), Proceedings of the International Workshop 'Local tsunami warning and mitigation', September 10-15, 2002, Moscow, 138-145, http://seac47-2.phys.msu.ru/procl

Saffer DM, Silver EA, Fisher AT, Tobin H, Moran K (2000) Inferred pore pressures at the Costa Rica subduction zone: implications for dewatering processes. Earth and Planetary Science Letters 177: 193-207

Schultheiss PJ, McPhail SD (1986) Direct indication of pore water advection from pore pressure measurements, in Madeira abyssal plain sediments. Nature 320: 348-350

Sibuet JC, and the 'Sumatra Aftershocks' team' (2005) « Sumatra Aftershocks » cruise report, (http://www.ifremer.fr/ drogm/Realisation/carto/Indien/Sumatra/) 105 pp.

Sibuet JC, Rangin C, Le Pichon X et al (2007) 26th December 2004 great SumatraAndaman earthquake: Co-seismic and post-seismic motions in northern Sumatra. Earth Planet. Sci. Lett. 263: 88-103.

Singh SC and the Sumatra-Aftershocks Team (2005) Sumatra earthquake research indicates why rupture propagates northwards. EOS 86: 497-502

Sultan N, Voisset M, Marsset B et al (2007) Potential role of compressional structures in generating submarine slope failures in the Niger delta. Marine Geology. Doi: 10.1016/j.margeo.2006.11.002

Stein S, Okal EA (2005) Speed and size of the Sumatran earthquake. Nature 434: 581-582

Urgeles R, Canals M, Roberts J (2000) Fluid flow from pore pressure measurements off La Palma, Canary Islands. Journal of Volcanology and Geothermal Research 101: 253-271

Von Huene R, Lee HJ (1982) The possible significance of pore fluid pressures in subduction zones. in: Studies in continental Margin Geology, J. S. Watkins and C. L. Drake, eds., AAPG Memoir 34: 781-792 
Tables

\begin{tabular}{llllll}
\hline Name & Type & Lat N & Lon E & Depth & Length \\
\hline MD05-2972 & Gravity & 4.294 & 93.196 & 3568 & 2.94 \\
MD05-2975 & Gravity & 4.254 & 93.210 & 3471 & 5.72 \\
MD05-2981 & Calypso & 4.105 & 93.083 & 4501 & 10.66 \\
MD05-PZ1 & Piezometer & 4.255 & 93.213 & 3484 & 3.5 \\
\hline
\end{tabular}

Table 1. Basic information on the sediment cores and piezometer from the "Sumatra Aftershocks" campaign.

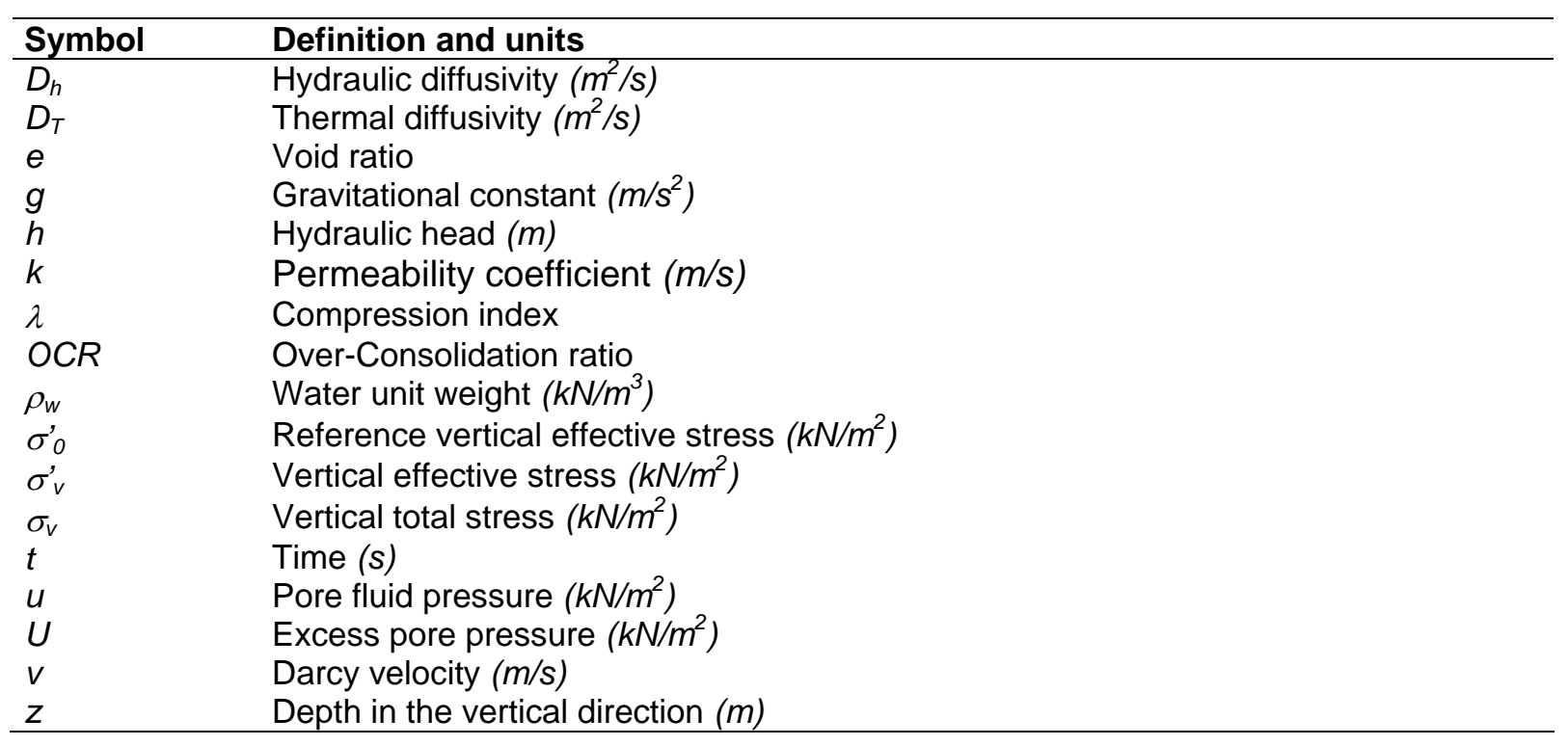

Table 2. Parameters and symbols used in this paper.

\section{Figures captions}

Figure 1. a Overview of the swath bathymetric data acquired during the "Sumatra Aftershocks" cruise (Sibuet et al., 2005). Black square locates the study area in the slope failure zone identified by Henstock et al. (2006) and the location of Figure 2. b) Cross section along the acquired bathymetric data showing the Aceh basin, the Sumatra accretionary prism and the trench. Black arrow (CS1) in Figure 1-a indicates the location of the cross section.

Figure 2. 3D bathymetric map showing a slide scar in the deepest part of the bathymetric data presented in Figure 1 (frontal area of the Sumatra accretionary prism) and location of cores MD05-2972, MD05-2975 and MD05-2981 and piezometer MD05-PZ1. Bathymetric sections A-A to E-E are in Figure 5.

Figure 3. Excess pore pressure at equilibrium obtained at two different levels (a: $11.6 \mathrm{mbsf}$ and $\mathrm{b}$ : $10.1 \mathrm{mbsf}$ ) from long-term (one week) monitoring and extrapolation. The maximum error between the real and the extrapolated equilibrium pore pressures is around $0.5 \mathrm{kPa}$ which is comparable to the precision of the pore pressure sensors. 
Figure 4. Shaded bathymetry of the slope failure zone identified by Henstock et al. (2006) showing the presence of at least three major sliding phases and associated blocks. Dashed lines show the location of 5 bathymetric cross sections presented in Figure 5. Slope angles higher than 20 degrees are projected on the shaded bathymetry map.

Figure 5. a) Three NE-SW cross sections across the northern part of the slope failure zone (A-A, B-B and E-E) showing the boundary of the eroded ridge crest (arrows A1 and E1) and folds/scarps due to faulting (arrows A2, A3, B1, E2 and E3) already identified by Henstock et al. [2006]. b) Two NE-SW cross sections across the slide 1, slide 2 and slide 3 indicated in figure 4 (C-C and D-D) showing several scarps which correspond to several phases of failures. The block Obj1 (see Figure 2 for location) is added (to scale) to the two cross sections c) Slope angle along the two cross sections C-C and E-E showing that the slope angle between those two cross sections are comparable and are lower than 17 degrees.

Figure 6. a) $3.5 \mathrm{kHz}$ profile across the block field associated to the different sliding phases from the flank of the frontal ridge (for location see Figure 4). Soft sediments covering the base of some blocks and an irregular, lens-shaped sediment deposit seem to confirm the presence of several sliding phases of different ages. b) $3.5 \mathrm{kHz}$ profile showing a seafloor escarpment with NW-SE trend. The location of core MD05-2981 is projected. c) Two X-ray Scopix images of selected intervals from core MD05-2981.

Figure 7. Sediment core MD05-2975 $4 \mathrm{~km}$ upslope of 'slide scar 3' is presented with a synthetic lithologic log, a unit weight curve and photo and/or X-ray Scopix images of selected intervals. Note the disrupted sediment structures between 4.4 and $4.8 \mathrm{~m}$ (down core) that could represent a remolded sedimentary unit.

Figure 8. The synthetic lithologic log and selected photo and/or X-ray Scopix images of sediment core MD05-2972 show a marked change in lithology occurs at $2 \mathrm{~m}$ (down core).

Figure 9. Geotechnical and physical data obtained from core MD05-2972 and MD05-2975. a) Unit weight b) compressional wave velocity c) water content d) liquidity index and e) undrained shear strength versus depth.

Figure 10. a) Oedometer tests carried out on 4 samples from MD05-2975 and b) permeability coefficients determined for 4 samples from MD05-2975 and at different consolidation states corresponding to different void ratios.

Figure 11. Over-Consolidation ratio OCR derived from oedometer tests carried out on cores MD05-2972 and MD05-2975 indicating that sediment in both cores is in Over-Consolidation state. The low OCR at around 4 mbsf in core MD05-2975 indicates remolded sediment.

Figure 12. Initial impulsion and dissipation of a) the temperature and b) the pore water pressure at three different levels generated by the piezometer MD05-PZ1 penetration (V1: $0.51 \mathrm{mbsf}, \mathrm{V} 2: 2.01 \mathrm{mbsf}$ and V3: $3.51 \mathrm{mbsf})$.

Figure 13. Extrapolation of the equilibrium pore pressures at 3 different levels (V1 $0.51 \mathrm{mbsf}, \mathrm{V} 2-2.01 \mathrm{mbsf}$ and $\mathrm{V} 3-3.51 \mathrm{mbsf}$ ) from 3 hours of pore pressure monitoring (site MD05-PZ1 - Figure 2).

Figure 14. a) Excess pore pressure and b) temperature versus depth at site MD05-PZ1. Comparison between the hydraulic gradient obtained from MD05-PZ1 and the lithostatic stress obtained from the unit weight of the core MD05-2975 shows that the pore pressure at $3.51 \mathrm{mbsf}$ corresponds to around $65 \%$ of the lithostatic stress. 
Figure 15. a) Excess pore pressure profile measured at MD05-PZ1 and calculated at different time-periods. The initial excess pore pressure is supposed to correspond to $90 \%$ of the lithostatic pressure in the area where we have identified the remolded sediment from core MD05-2975. Design profiles used in the calculation for b) the void ratio and c) the permeability coefficient.

Figure 16. Excess pore pressure considered as a result of slab subduction and evaluated under a steady state regime with a pore pressure source at a) $100 \mathrm{mbsf}$ b) 50 mbsf and c) 25 mbsf. The lithology over the calculation depth is considered as homogeneous.

Figure 17. Excess pore pressure considered as a result of slab subduction and evaluated under a steady state regime. Hydro-fracturing is supposed to occur below $5 \mathrm{~m}$ inducing an important increase of the permeability coefficient to $5.10^{-5} \mathrm{~m} / \mathrm{s}$. a) excess pore pressure calculated and measured and b) temperature profile calculated and measured. 
a)

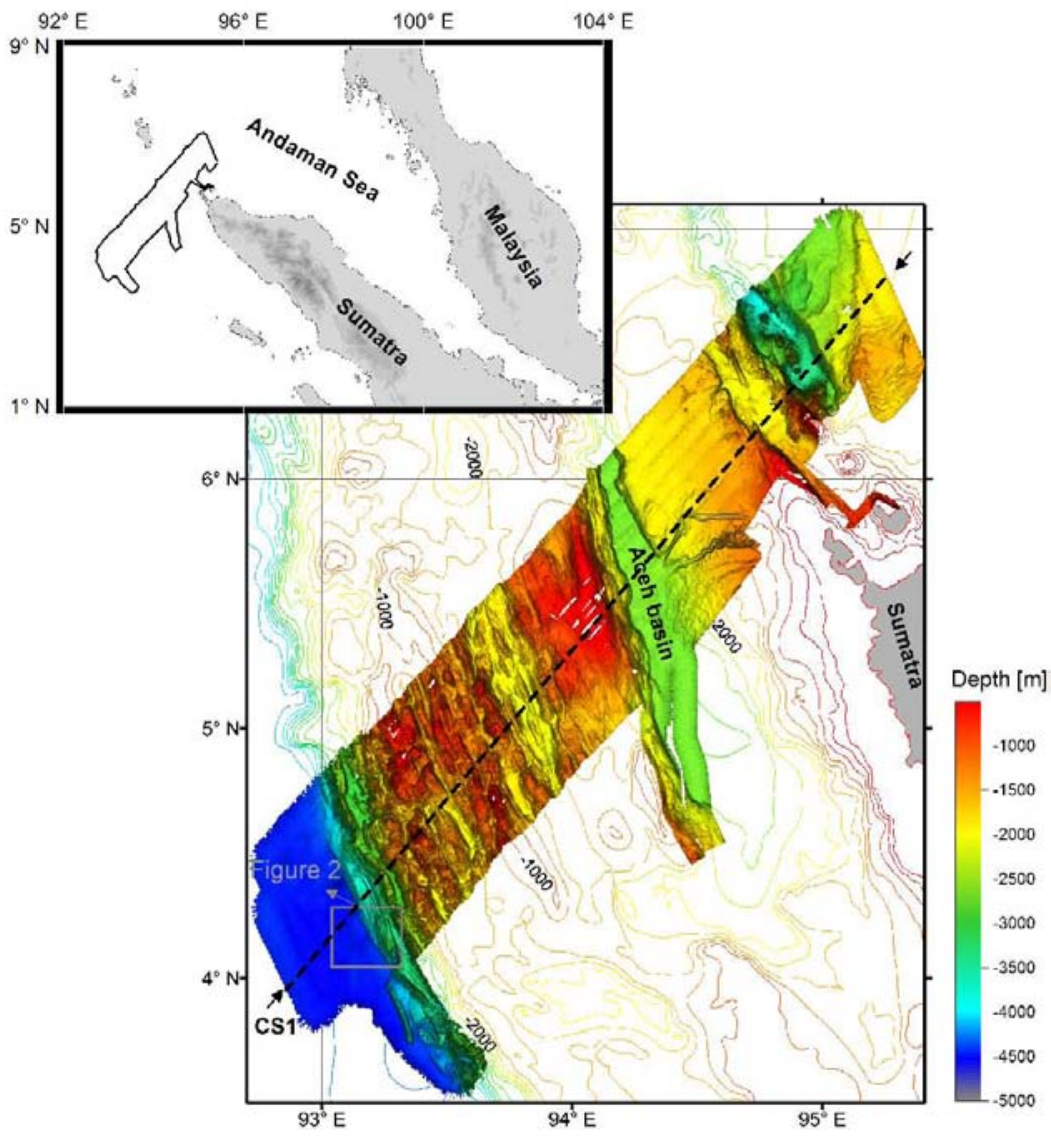

b)

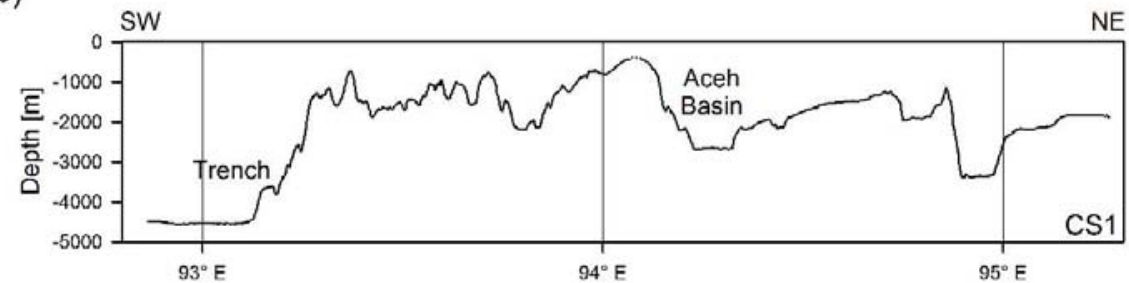




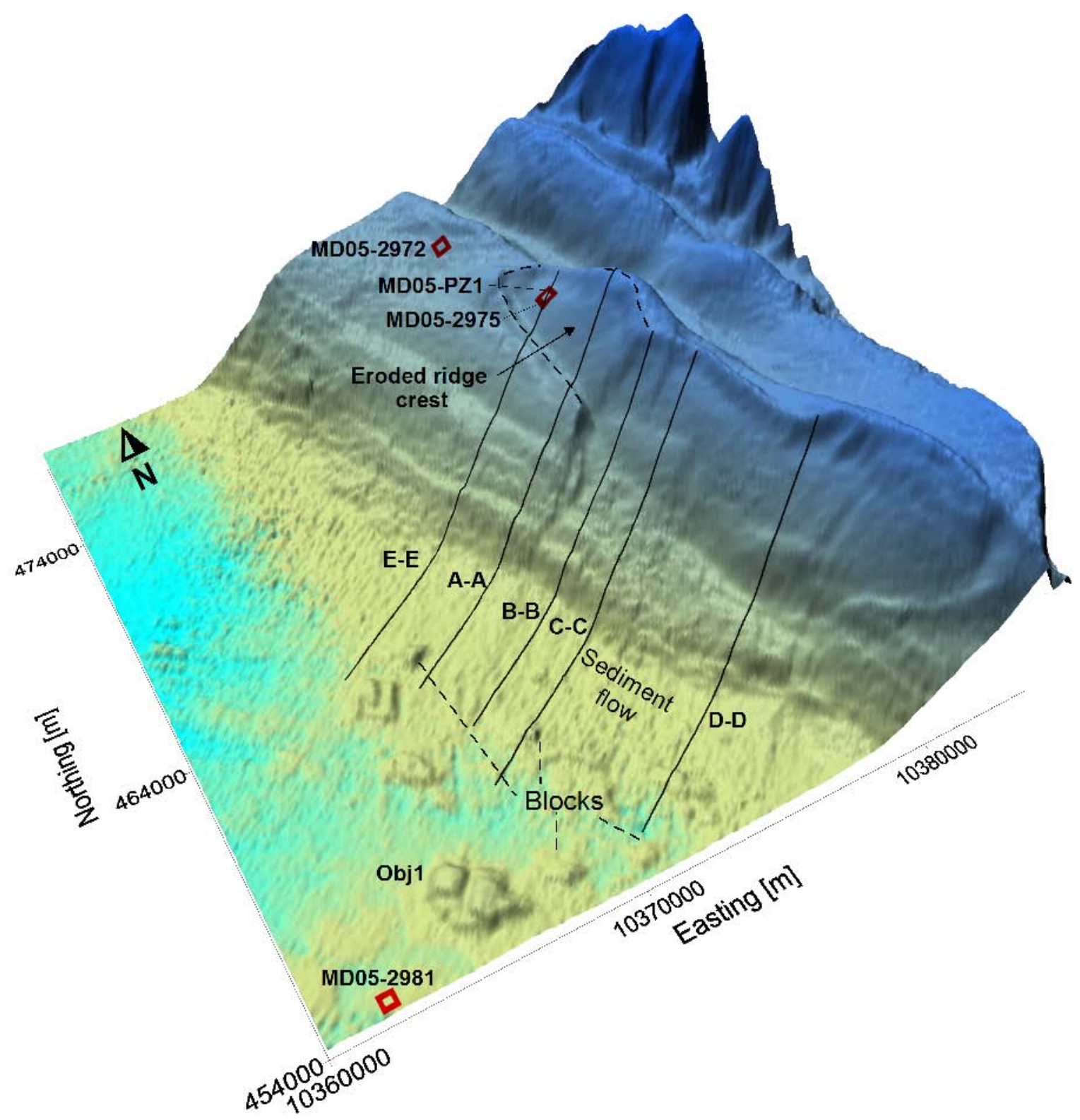



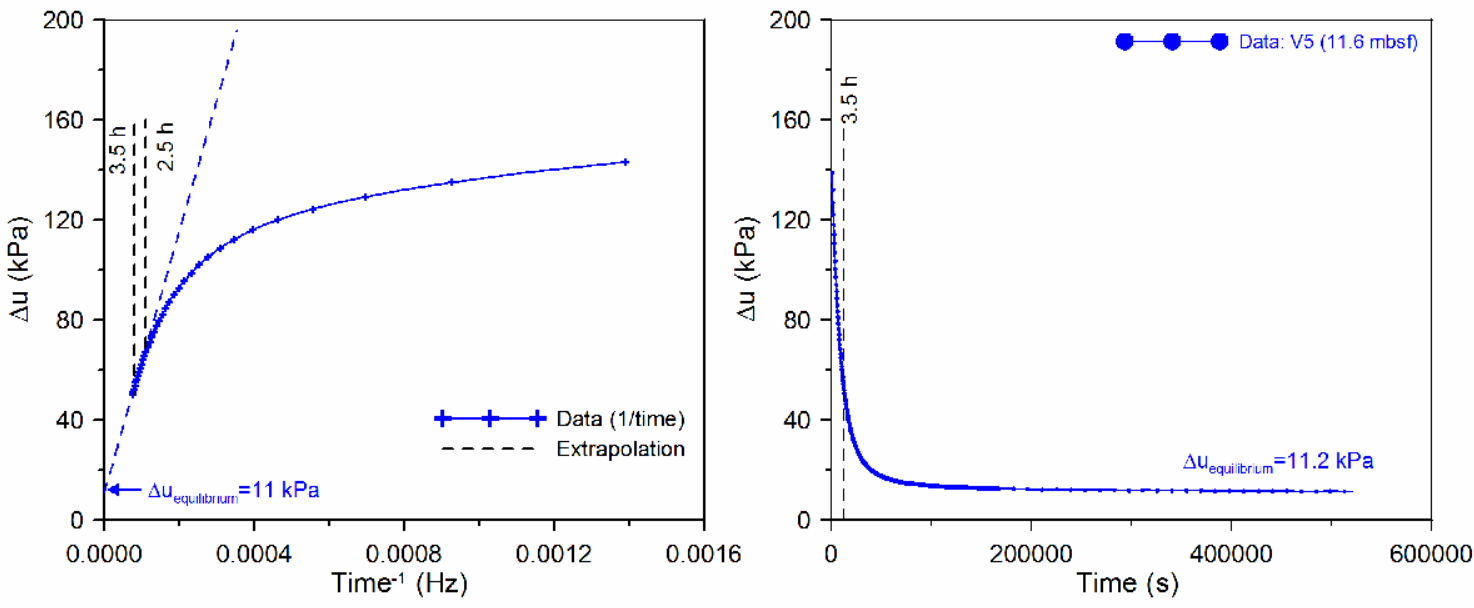

b)
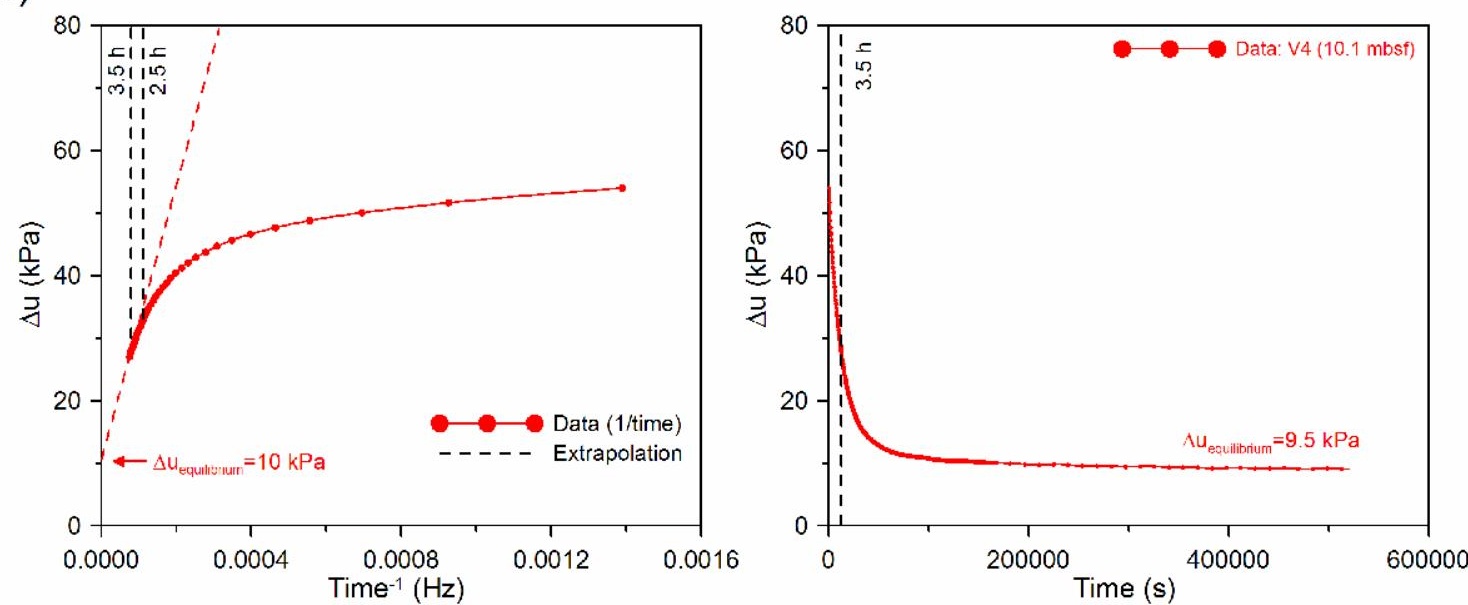


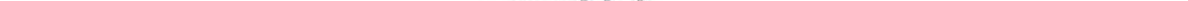



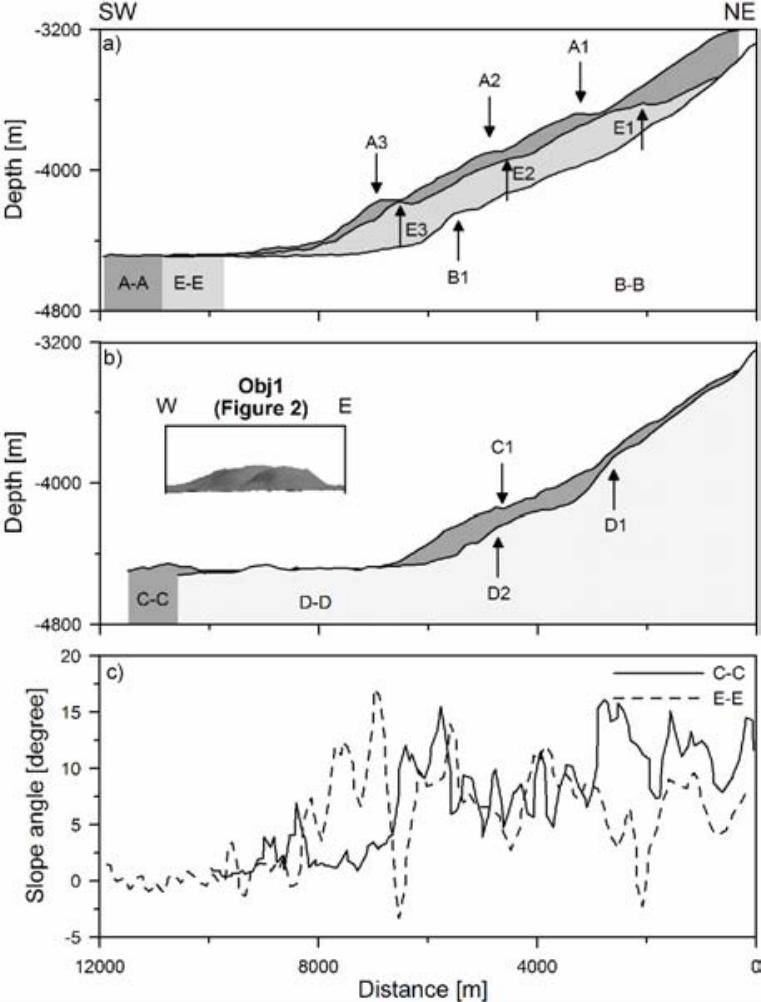

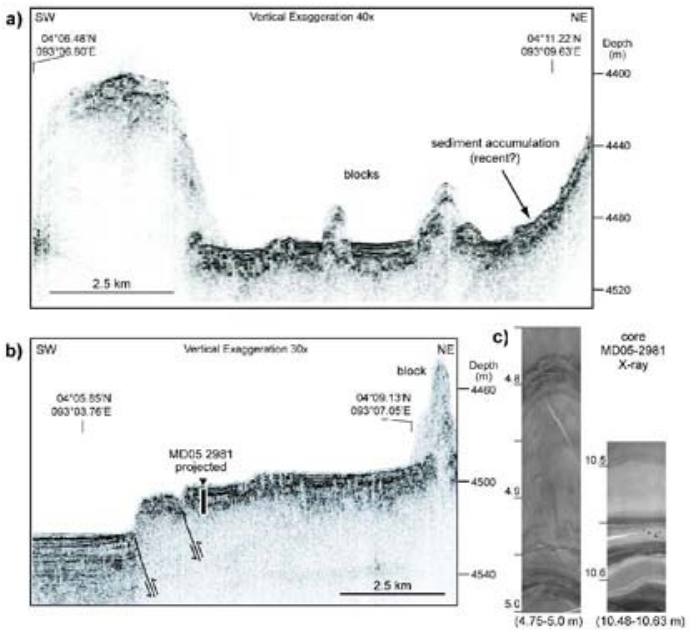
a)
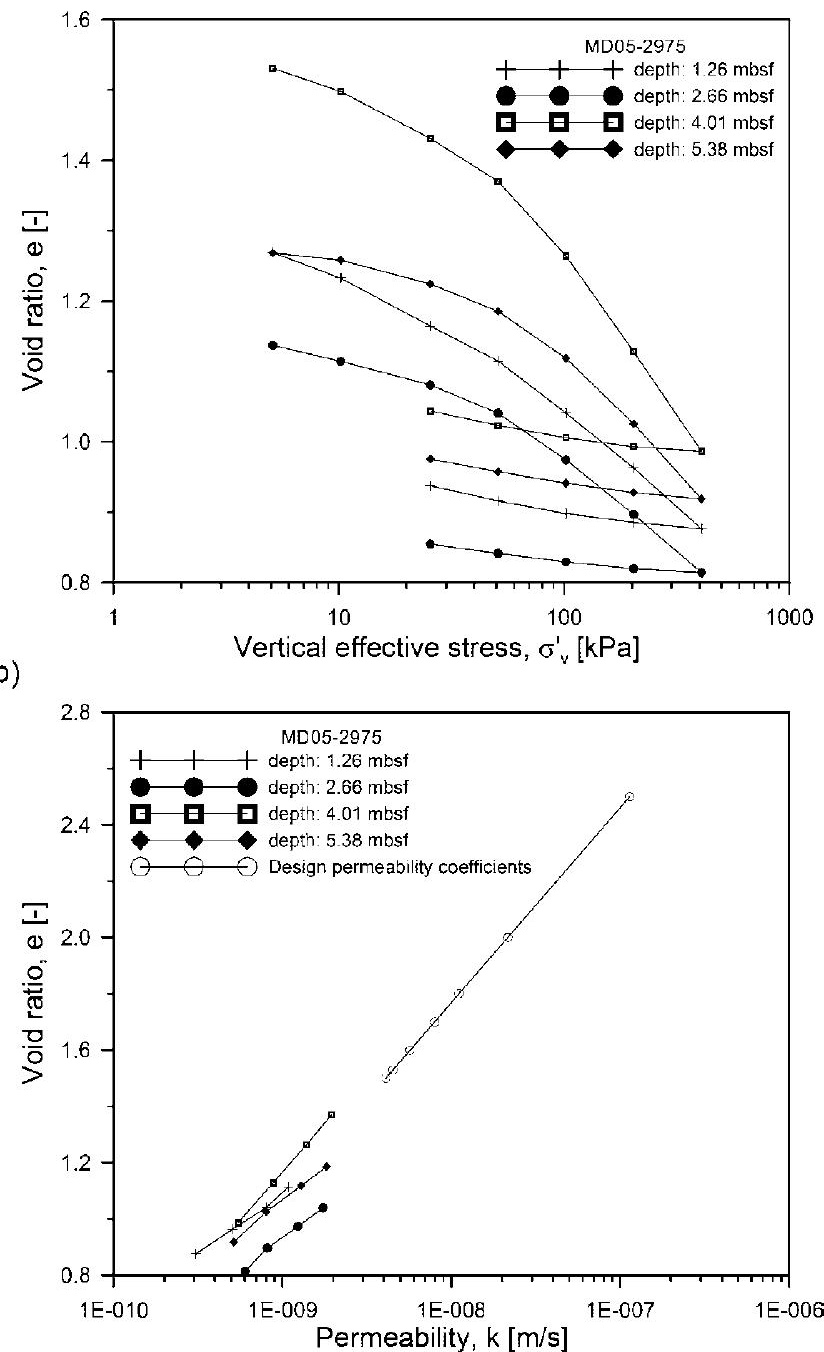


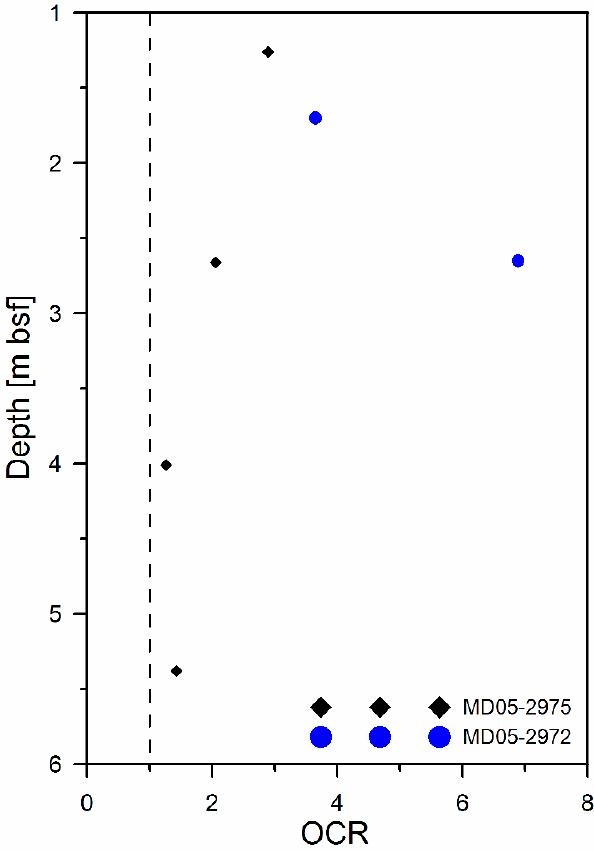




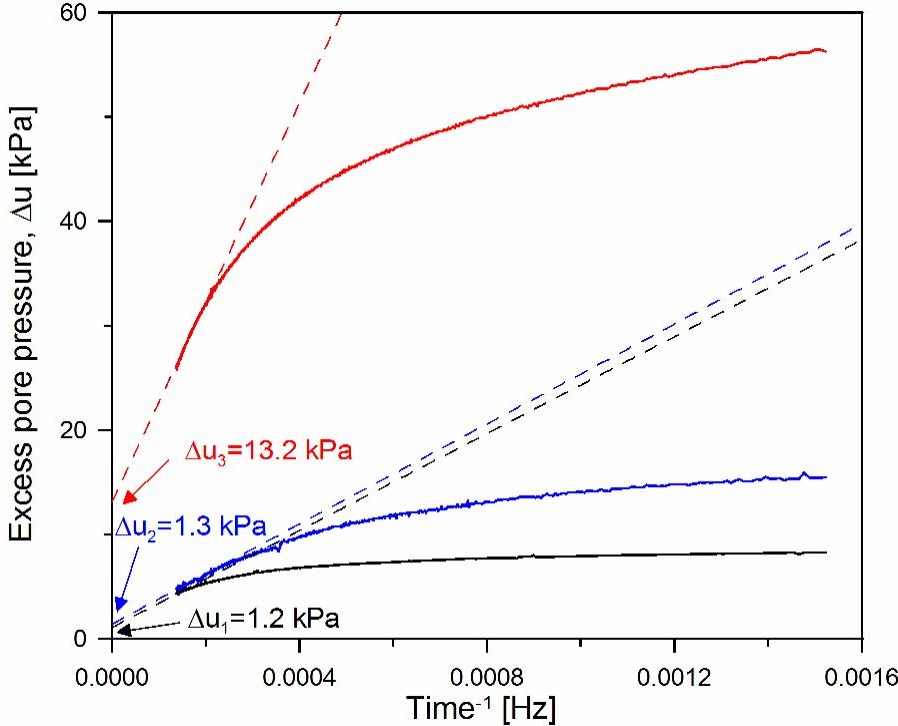




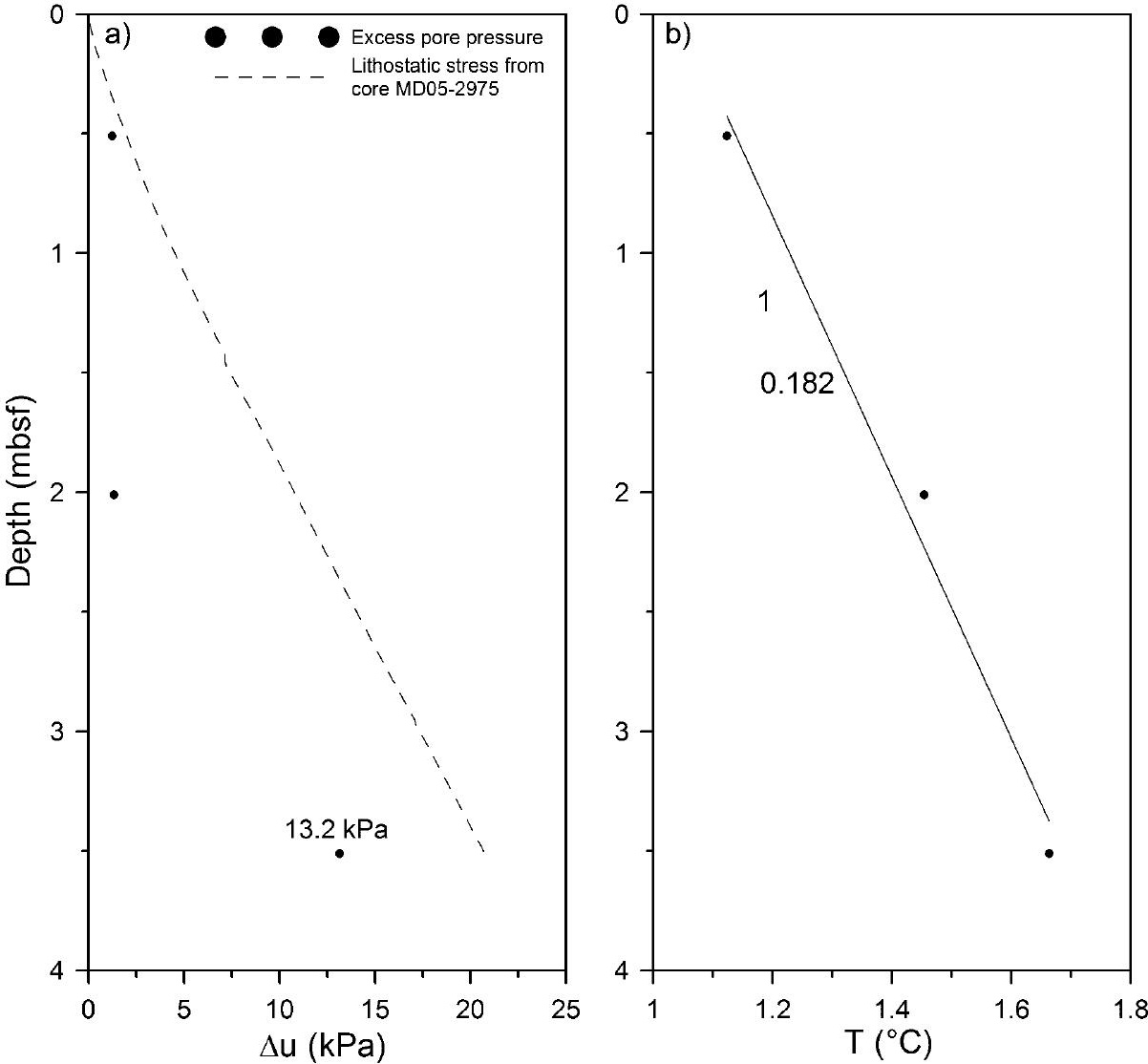




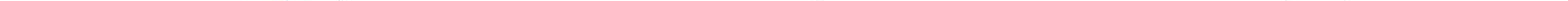


a)

b)

c)

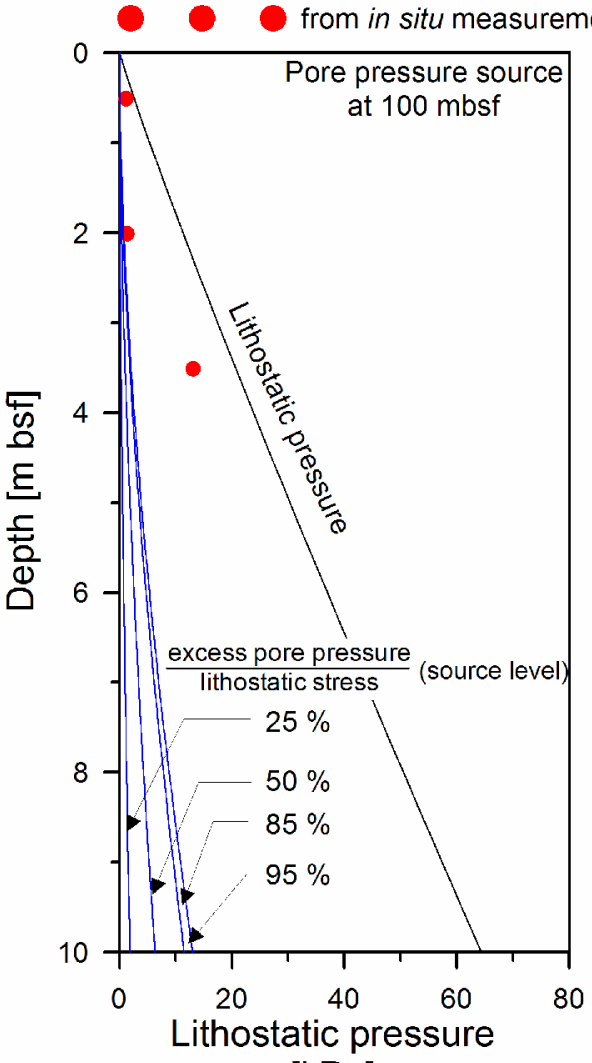

[kPa]

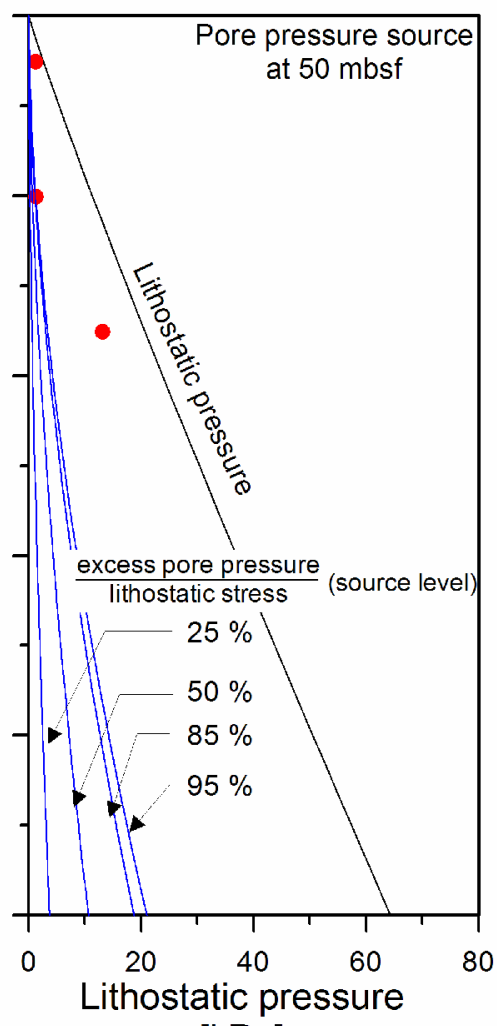

[kPa]

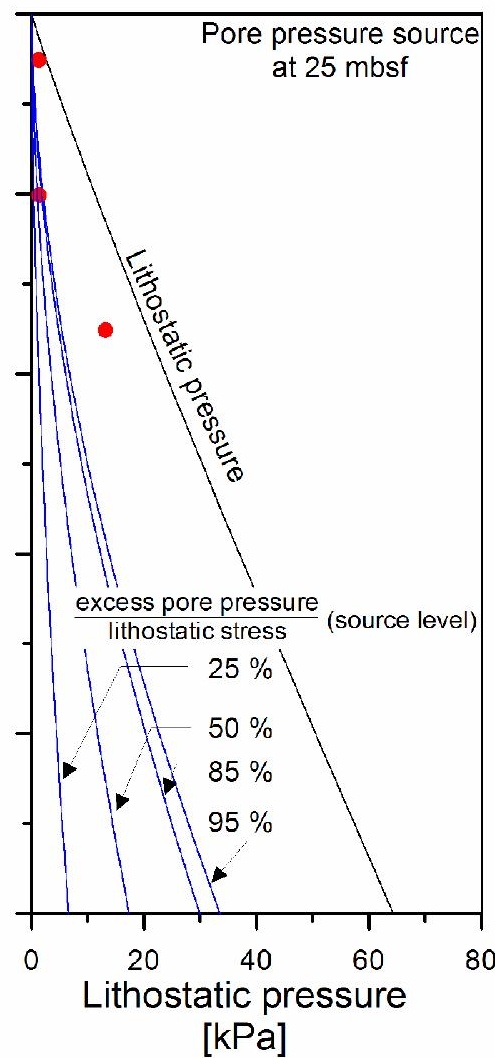




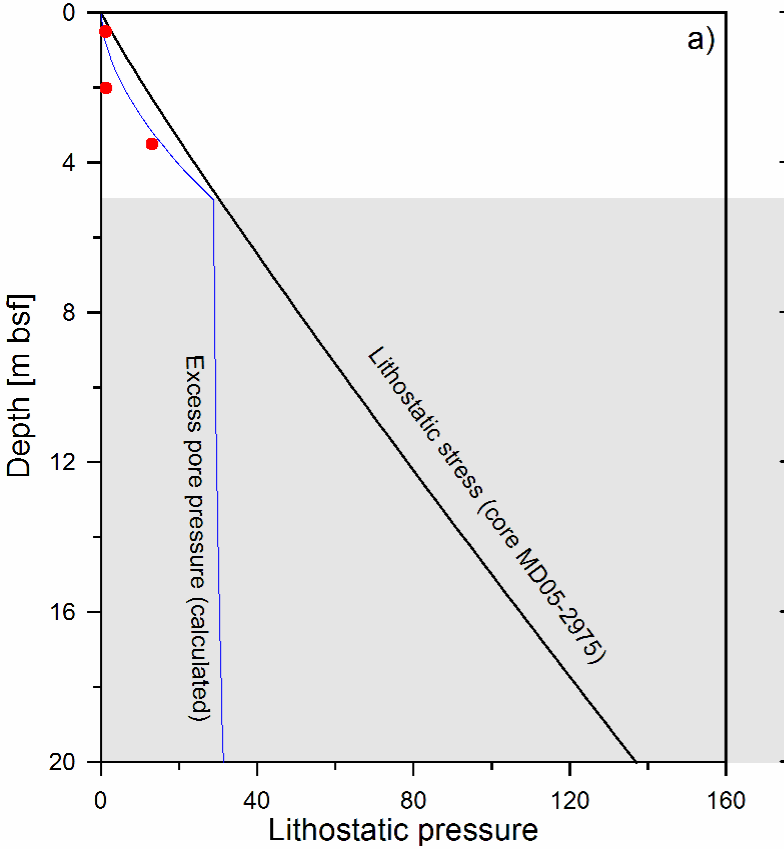

[kPa]

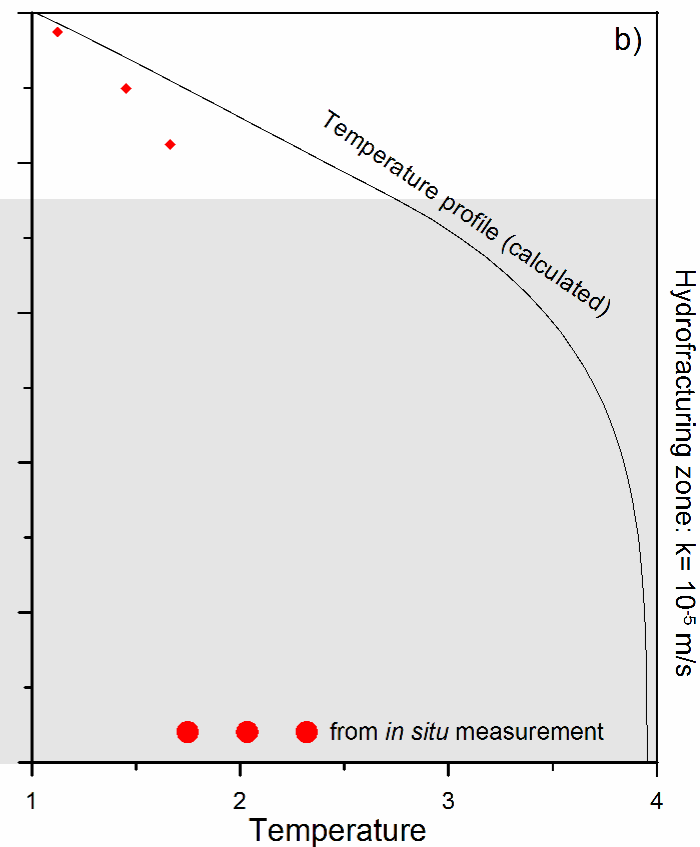

$\mathrm{T},\left[{ }^{\circ} \mathrm{C}\right]$ 